\title{
Know What Is, and Know What Ain't An Actor's Exploration into Developing the TopdogUnderdog Character Lincoln
}

\author{
Lonnie DeVaughan Simmons
}

Follow this and additional works at: https://researchrepository.wvu.edu/etd

\section{Recommended Citation}

Simmons, Lonnie DeVaughan, "Know What Is, and Know What Ain't An Actor's Exploration into Developing the TopdogUnderdog Character Lincoln" (2018). Graduate Theses, Dissertations, and Problem Reports. 6646.

https://researchrepository.wvu.edu/etd/6646

This Thesis is protected by copyright and/or related rights. It has been brought to you by the The Research Repository @ WVU with permission from the rights-holder(s). You are free to use this Thesis in any way that is permitted by the copyright and related rights legislation that applies to your use. For other uses you must obtain permission from the rights-holder(s) directly, unless additional rights are indicated by a Creative Commons license in the record and/ or on the work itself. This Thesis has been accepted for inclusion in WVU Graduate Theses, Dissertations, and Problem Reports collection by an authorized administrator of The Research Repository @ WVU. For more information, please contact researchrepository@mail.wvu.edu. 


\title{
Know what Is, and Know what Ain't
}

An Actor's Exploration into Developing the Topdog/Underdog character Lincoln

\author{
Lonnie DeVaughan Simmons
}

Thesis submitted to the College of Creative Arts

West Virginia University

in partial fulfillment of the requirements

For the degree of

Master of Fine Arts in Acting

Laura Hitt, MA

Irene Alby, MFA

Jules Malarcher, Ph.D.

School of Theatre \& Dance

Morgantown, West Virginia

2018

Keywords: Topdog/Underdog, Acting, Theatre

Copyright 2018 Lonnie DeVaughan Simmons 


\section{ABSTRACT \\ Know what Is, and Know what Ain't. An Actor's Exploration into Developing Lincoln from Topdog/Underdog Lonnie DeVaughan Simmons}

The playwright Suzan Lori-Parks is known for writing intense, psychological plays featuring mostly characters of color who have depth and emotional richness. Topdog/Underdog is a prime example of this. The play features two brothers who live in a cramped apartment and deal with issues of their past and their relationship with each other. I would like to argue that portraying Lincoln in the West Virginia University production of Topdog/Underdog was an intense and rewarding process where I had to consider race and what it means to be performing this play with the state of our country at the time, utilize acting techniques learned during my time at WVU, find the musicality of the language, find the separation between character and actor and perform a contemporary play that audiences can relate to, no matter what their skin color or background is. Through script analysis and table work, the characters and their relationship were fleshed out between the two actors and the director. Utilizing Meisner, Laban and Fitzmaurice technique allowed me to delve into the mindset of the character. 


\section{TABLE OF CONTENTS}

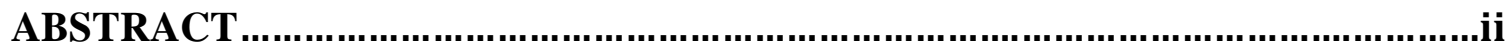

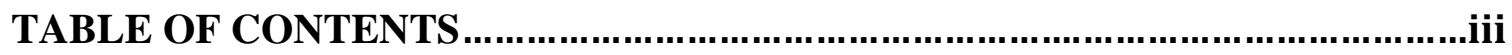

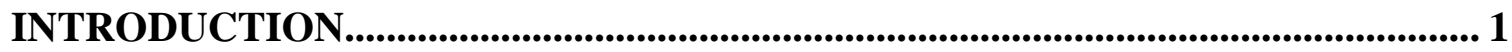

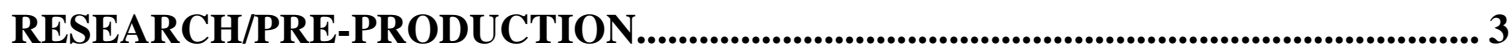

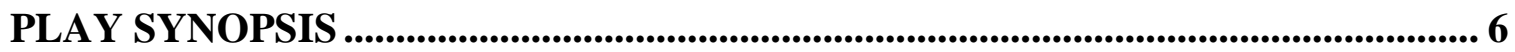

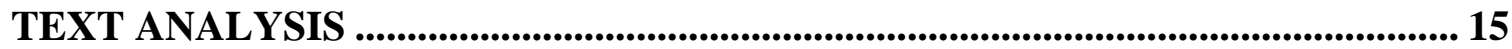

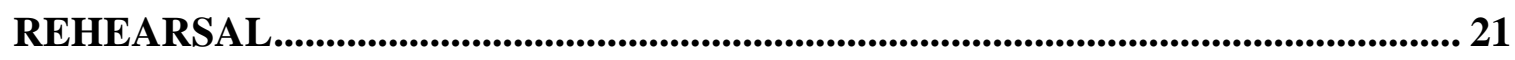

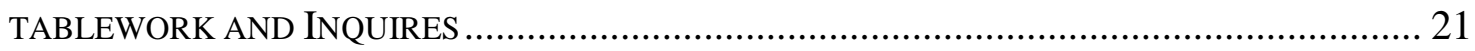

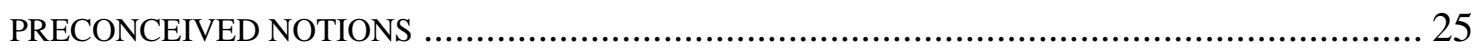

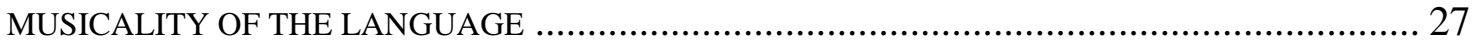

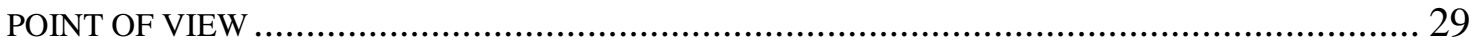

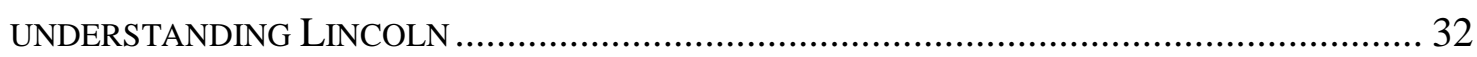

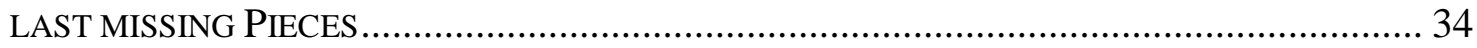

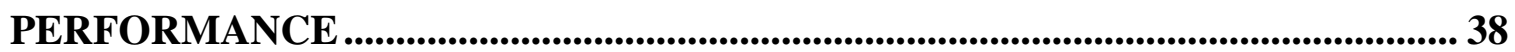

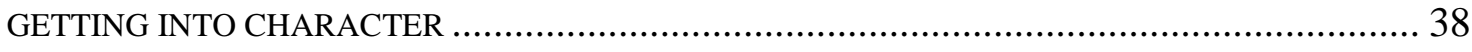

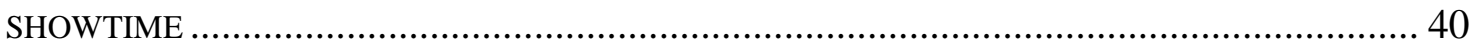

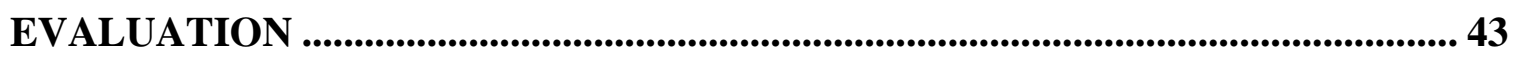

CONCLUSION ........................................................................................................................ 45

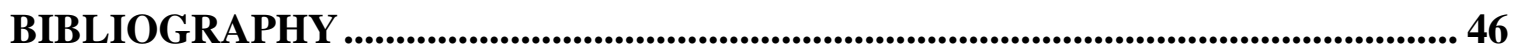




\section{$\underline{\text { Introduction }}$}

Plays are meant to tell the stories of characters. The best plays find a way to uniquely show the individuality of the characters while also having universal themes. The play Topdog/Underdog by Suzan-Lori Parks does this well. This play about two African-American brothers living in a cramped apartment is extremely contemporary, visceral, and poignant. The play originally performed in July 2001. It went on to win the 2002 Pulitzer prize for drama. The cast consists of Lincoln and Booth, brothers ironically named by their father after President Abraham Lincoln and his assassin, John Wilkes Booth. Both of their parents left them at a young age which forced them to fend for themselves. To survive, Booth became adept at shoplifting, while Lincoln turned his sights to hustling through the tricks of playing the game 3-card monte. Lincoln earned respect for his talent with the cards. Booth longed to play the cards like his brother. After the death of Lincoln's friend, Lonny, he made a major change to his life deciding to give up the cards and get an "honest" job. This decision resulted in a job playing President Abraham Lincoln at an arcade. People came to reenact Lincoln's assassination. They would stand behind him and shoot him in the head. The play opens in a small apartment, rented by Booth, where both brothers live. From this point, the journey of the play spirals downward as both brothers compete to see who lands on top and who lies underneath. The entire action of the play takes place in the small apartment.

As an actor, this would be my first two-person play. The journey from our read-throughs to the performances proved one of the most difficult and rewarding challenges I have faced. Aspects of the play and the character led me to question things about myself and the world around me. I would like to argue that portraying Lincoln in West Virginia University's (hereafter referred to as WVU) production of Topdog/Underdog was an intense and rewarding process. 
I had to consider several factors: 1) the element of race and what it means to be performing this play during this particular historical period within our country, 2) how to utilize acting techniques learned during my time at WVU, 3) to find the musicality of the language, and 4) to find the connection and separation between character and actor while performing a contemporary play that audiences relate to no matter their skin color or social background. The play focuses on the deep relationship and inherent struggles between two brothers, a universal story that many can connect with. I have felt personally connected with this play for years. To develop a role that I have longed to perform, to bring it to fruition on the mainstage, made all of my hardships and difficulties worth it. 


\section{$\underline{\text { Research/Pre-production }}$}

The story of Topdog/Underdog at WVU does not start with the announcement of the 2017-18 theatre season. It begins during my first year at WVU in the MFA program.

Topdog/Underdog had been a play long close to my heart. I read the play during my time in my undergraduate program. I grew a fascination with the characters. Being a younger brother myself, it drew me in. The story of the relationship, the challenges and struggles between the two siblings to become realized individuals independent of one another proved incredibly powerful to me. I became an instant a fan of the play. Before graduate school, finding a chance to produce and perform the play appeared very difficult, if not impossible, to accomplish. At the time I lived in Washington DC, where the play is rarely produced. Even if I put the play up myself, finding another actor that I trusted, who had the same love for the play, would be more difficult. It became a pipe-dream. I performed monologues from the play while I longed for the chance to be in a full production.

In 2015, I started graduate school. I met my classmates, including Andra Ward Jr, a fellow African-American male actor. As I went through my first year of school at WVU, I got to know Andra. I discovered he was also a fan of Topdog/Underdog and always wanted to perform in the play. In addition, he desired to play Booth while I desired to play Lincoln. We began discussions about how we would find a way to put the show up during our time at WVU. In West Virginia University's theatre program, students may submit suggestions for the mainstage season. Andra and I both submitted the play as an option for the season. However, we did not expect anything to come from it. We planned to do the play as a lab show. A lab show differs from a mainstage show. A mainstage show is a full-production with a set designer, costume designer, a lighting designer, a props master, a stage manager and crew. This team of 
collaborators all support the performances on the mainstage. In contrast, a lab show production is performed in one of the black box theatres and receives little support or resources to enhance production values. Despite the lack of resources offered a lab show, we were determined to find a way to perform this play about which we were both so passionate. We told ourselves the show was going to be put up, with or without the resources of the school. To our surprise, the show was selected as a mainstage show for the Fall 2017-18 season, to be performed in rotating repertory with another show. perform Topdog/Underdog one night and the next night, the other play would be performed. I was happy to perform the play on the mainstage where it would receive greater visibility within the College and community. However, I started to wonder how a play like this, featuring two African-American men, would be received in West Virginia.

My second year of graduate school saw our country in transition. A presidential election took place. The winner of the election was Republican candidate Donald Trump. Due to Trump's obvious racial bias throughout his campaign, the area of Morgantown changed. People who hid their discriminatory thoughts and behaviors now felt comfortable expressing these thoughts and behaviors aloud and visibly. Confederate flags popped up out of nowhere. Occurrences in which women and people of color were harassed took place around campus. I already felt uncomfortable as a black man in this area, but in 2016, I suddenly felt unsafe.

I was ecstatic about the selection of Topdog/Underdog for the mainstage season, but I felt concerned telling this particular story in West Virginia. Growing up in DC allowed me the opportunity to encounter people from many different walks of life. People move to the DC area from all around the world. While the city of Morgantown is similar, in that it is a hub for many different people and cultures, the state of West Virginia may not necessarily be the same. Even if one looks at the past play production history at WVU, there has never been a play starring two 
African American men. Due to these factors, I was unsure how the audiences would react to the characters and subject of the play. Would they accept it, or would they reject it? And if they rejected it, how intensely would they reject it?

All of these questions plagued my mind as I thought about performing in this play. At this point, I knew the best thing to do was concentrate on the work. I decided to focus on telling the story of these two characters instead of on my concerns. Once we found a director, we could begin.

WVU decided to bring in a guest director for the production. The first director we were in touch with was Cleo House, a director from Atlanta. My first interaction with Cleo was through email where he told us to prepare monologues and scenes for an audition. Andra and I went into this audition with hesitancy as we already knew what characters we were drawn to. After a very quick Facetime audition with the director, he cast the roles. I was cast as Lincoln and Andra was cast as Booth. I believe part of the decision came from my ability to play the guitar. The script calls for Lincoln to play the guitar. Once casting was complete, I began analyzing the play. Unbeknownst to Andra and I, Cleo would drop out as director for the show. Eventually, another director was hired, Jade King Carroll.

Once we knew the casting choices and director, it was time to dive into the analysis of the play and my character, Lincoln. Naturally, as an actor, the best source of information for one's character is the text itself. The first thing to tackle is to understand the story of the play. 


\section{Play Synopsis}

Topdog/Underdog, opens with Booth alone on stage playing the card game 3-card monte. Lincoln then enters dressed as if he is Abraham Lincoln. He wears an outfit which entails a frock coat, top hat, and a fake beard. His face is also covered in white make-up since he is black. We learn that Lincoln's day job is an Abraham Lincoln re-enactment impersonator at an arcade. Similarly to how the $16^{\text {th }}$ president of the United States, Abraham Lincoln, was assassinated, every day he sits in a chair with his back to the customers and is shot by customers in the back of the head. This relates to the meaning behind the names of the two brothers. Lincoln's younger brother is named Booth, similar to John Wilkes Booth, the man who assassinated President Abraham Lincoln. While the characters are not named after the two historical figures, the reason they are named Lincoln and Booth does have a significance with regards to the end of the play. Their father even tells Lincoln why, at the end of scene 1, "It was his idea of a joke" (Parks 29).

At the start of scene one, Lincoln surprises Booth as he enters. The apartment they live in is rented by Booth. It is a cramped tenement apartment. It has no bathroom and no kitchen. The room consists of a bed and an old recliner. Booth sleeps in the bed and Lincoln sleeps on the recliner. The recliner is known by the two brothers as Lincoln's space. He does not have any personal space of his own in the apartment. As he enters, Booth, feeling jumpy, pulls out a gun and points it at him and says "Who thuh fuck you think you is coming in my shit all spooked out and shit. You pull that one more time I'll shoot you!". (13) Lincoln persuades him to put the gun down, which he does. As Lincoln proceeds to get undressed, the two brothers tell each other about their respective days. They then sit down to eat. Booth finishes his meal and resumes playing 3-card monte. 
3-card monte is a game played with 3 cards. One card happens to be a different suit than the others. Lincoln uses the two of spades and two red cards. The cards are placed down and moved around in a certain pattern. The moving of the cards then stops. To win the game, one must find the card that is a different suit. In the case of Lincoln's 3-card monte, a person must find the two of spades. The dealer wins by tricking the person into picking the wrong card.

It becomes apparent in the scene that in fact, Lincoln is the expert of this game, not Booth. Lincoln teaches Booth by saying "You wanna hustle 3-card monte, you gotta do it right, you gotta break it down, Practice it in smaller bits, Yr trying to do the whole thing at once that's why you keep fucking it up.”. (23). Booth takes this learning opportunity to convince Lincoln to begin to hustle again. Booth wants to play the game, thinking he can sway the woman he likes, Grace, back to him. Lincoln made the choice before the play begins, not to hustle anymore. He decides to no longer hustle due to the death of his friend and partner, Lonny. Lonny was shot in front of Lincoln during a day of hustling.

The two brothers argue, and it builds to a moment that could lead into a physical altercation. They both back off before it does. Lincoln reaches out to Booth for reconciliation over the argument by bringing up their father. Lincoln tells Booth why their father named them Lincoln and Booth, which draws Booth's attention. Lincoln tells him that it was their father's idea of a joke.

In the second scene of the play, Booth enters hiding things under his clothes and takes out all that he stole from clothing stores. He has stolen two suits, two pairs of shoes, two ties, two shirts and two belts. Lincoln enters waving around a handful of money. He has just been paid by his job. The two joke around with each other and Booth shows Lincoln the stolen clothing. Both brothers try on the suits, bonding while reminiscing about their father, who also wore and owned 
very nice suits. After they strut around the apartment, Booth proceeds to divvy out the money, that Lincoln earned, for rent and bills. Lincoln ends up with only fourteen dollars of his own money.

Lincoln then describes the various aspects of his job and why he endures his work. "The smell of the ocean and cotton candy and rat shit, and in the middle of all that, I can sit and let my mind go quiet. Make up songs, make plans, Forget." (38). He also states he is in danger of getting fired. Booth commiserates with him and gives him tips on how to better re-enact Abraham Lincoln. Lincoln begs Booth to stay and practice with him, but Booth has plans to go out with Grace. Booth promises to help him later and leaves. Lincoln decides to practice by himself. Lincoln changes back to his Abraham Lincoln outfit and practices re-enacting his assigned death scene from the arcade. The scene of the play ends with Lincoln finishing up his rehearsal of death, to then drink heavily until he passes out in a chair.

In the third scene of the play, Booth enters to find Lincoln asleep in his chair. After purposefully waking up Lincoln, Booth proceeds to brag about his sexual conquest with Grace. Lincoln calls him on his bluff and asks Booth for more details about his date. Booth gives an exaggerated description of his night and Lincoln feeds into it by hyping him up, knowing full well Booth did not sleep with Grace. Lincoln then asks Booth to keep his promise to help him practice his Abraham Lincoln death scene. Booth says he is too tired. At this point, Lincoln exclaims that Booth did not have sex with Grace. The two argue intensely. Now the deeper, and more dangerous competition between the brothers begins to be evident. The scene ends with Booth challenging Lincoln's manhood. Booth refers to Lincoln's inability to keep his ex-wife, Cookie, due to his impotency. He then rubs it in Lincoln's face by boasting that he slept with 
Cookie. This argument ends with the two brothers at another silent confrontation. The tension builds. It is as if they are fighters in a ring and they both go to their respective corners.

Lincoln breaks the awkward silence by bringing up 3-card monte. He appeals to Booth's desire to learn the game from him. Lincoln persuades Booth to talk to him. He has the idea of getting Booth together with his old 3-card monte crew. He states that they would take Booth on as a team member with his say. By reeling Booth in, he reestablishes his role as top dog in the relationship. The conversation then moves towards fire arms. Lincoln tells his brother he will have to get a better gun for hustling. The two go back and forth debating each other's knowledge of guns. It ends with Booth taking another jab at Lincoln's sexual impotency. Booth then changes the subject to Lincoln's job.

Booth asks Lincoln if he ever worries that someone will come in with a real gun and shoot him. Lincoln tells him that he does not worry about this possibility. Booth then questions Lincoln's statement and asks him if he sees who is shooting at him. Lincoln responds saying that he does not, that he stares straight ahead like Abraham Lincoln did when he died. Booth does not back down and pushes the question. This provokes Lincoln to describe what his job is like. He goes into specific detail of his experience, beginning with the darkness of the room while he sits waiting for customers to enter. He explains the silver metal box in front of him and the sound of the footsteps of people behind him. He conveys the feeling of the customer behind him and the cold gun that touches his neck. After the customer shoots, Lincoln tells Booth he slumps down and pretends to die while the many different clients leave the room feeling satisfied. Lincoln ends the description of his job with the exclamation that he sorely wants to keep his job.

After seeing how important Lincoln's job is to him, Booth finally gives in and decides to help Lincoln practice his re-enactment. A series of tries involves: a) Booth pretending to shoot 
Lincoln, b) Lincoln faking his death, and c) Booth giving feedback. Booth proceeds to give one more aggressive note for Lincoln to "go all out". Lincoln does so and shocks Booth with how authentic it looks. Lincoln asks for feedback and Booth says it looks too real. Lincoln explodes, going into a tirade about how Booth is trying to get him fired. He touches on how "neat" and "polished" people want their history to look as opposed to the reality of how "raggedy and bloody" it is. He tells him how hard it is for him to keep his job: that to play Abraham Lincoln, as a black man, presents an obvious and inherent challenge. Lincoln delves into his past and the path that led him to take the job in the first place. He gave up hustling, began to drink more. He tells his brother that Cookie threw him out. Desperate, he needed a job, and this was the only one he could find. He ends his speech exclaiming that he does not want to get fired. Booth immediately shifts the conversation to Lincoln returning to hustle. Lincoln adamantly says no. The scene ends with Lincoln falling asleep in his chair and Booth, in a display of brotherly love, putting a blanket over Lincoln.

In scene four, Lincoln awakens from his drunken sleep in the middle of the night desperately needing to pee. Booth is fast asleep in his bed. After he pees in a nearby cup, Lincoln becomes annoyed that he has fallen asleep in his Abraham Lincoln outfit. He then begins to claw at the uniform trying to get it off. While taking it off, he rips the beard and goes on a diatribe to himself about his job and his boss. But even so, he convinces himself that it is a good job with benefits and he should not complain. This line of thought leads him to think about hustling and the status that he once possessed. He describes how good he was at 3-card monte and how he was revered by others. These memories lead him to think about why he stopped hustling. Lincoln woke up one day and had a premonition that he shouldn't play 3-card anymore. After he forced himself to play one more time, his best friend and right-hand man, Lonny, died that day. The 
death of Lonny immensely affected Lincoln. He was fearful that what happened to Lonny could happen to him. He would rather be alive than make a lot of money hustling. While reflecting on Lonny's death, he tells himself that now he indeed has a good, steady job and if he loses that job, he can get another. He is determined to not return to the inherent dangers of street hustling.

Nonetheless, he continues to reminisce with pride about how accomplished he was as a 3card monte player. He remembers how he would hustle unsuspecting rich people, how he approached the hustle, and how much money he was able to gain from people. He goes back and forth reminiscing how good he was and how he had sworn off the cards. After the long discussion with himself, the allure of the success at cards reels him in. For the first time in the play, he picks up the cards. At this moment, Booth awakens to observe Lincoln. Lincoln begins to play 3-card monte but instantly regrets it. He throws the cards down. The scene ends with Lincoln asking God for help.

Scene five opens with Booth, nicely dressed, preparing the apartment for Grace's arrival. He has stolen china, silverware, candles and tablecloths to impress her when she comes to dinner for their special intimate date. However, Grace is running very late. Booth feels impatient and even observes that the food is getting cold. A drunken Lincoln enters the apartment carrying most of his Abraham Lincoln work outfit. Booth tries to persuade Lincoln to leave but Lincoln barges in proclaiming that he lost his job. Lincoln is determined to stay in the apartment until Grace gets there. While Booth waits in anticipation for Grace, Lincoln settles in and begins to look at an old family photo album, proceeding to travel down memory lane. He thinks about the brothers' upbringing. He recalls the house they grew up in, the meals they ate, and the actions of their parents. Booth reluctantly joins him on the mental journey. 
Lincoln then describes the struggles of the two parents. He believes they were running from something inside them and they left Lincoln and Booth alone because they could not escape it. Booth counters that their mother and father had a plan set in motion to abandon the two children. He states that it is too much of a coincidence that their mother left Booth an inheritance of 500 dollars and their dad left Lincoln the same inheritance. Booth also takes this opportunity to again bring up the idea of the two brothers playing 3-card monte together and returning to a life of hustling.

Lincoln finally relents and agrees to teach his little brother how to play. He teaches the hustle of 3-card monte to Booth, including the terminology, process and roles involved. They proceed to play 3-card monte with Lincoln throwing the cards. Booth picks the right card every time. Booth breaks out into an extravagant show of victory over his brother, much to Lincoln's dismay. Lincoln then allows Booth to throw the cards which he does in an over-the-top manner. Lincoln laughs at Booth's style of 3-card monte and berates him by bringing up past losses caused by Booth. He then taunts Booth by responding to his mention of Grace. Booth becomes upset and storms out, leaving Lincoln alone with the cards. The scene ends with Lincoln playing 3-card monte faster and faster, showing that he still has his master skills and that, despite himself, still enjoys the game.

Scene six opens with an inebriated Lincoln entering a seemingly empty apartment. He checks to see if his brother is there and then proceeds to pull out a large wad of money he won playing 3-card monte on the street. He declares aloud how well his day of hustling has been. He talks about how he is back and still great at 3-card monte. He also talks about how his impotency issues have gone away and how women were crawling over him. He then exclaims that the world 
thought he was down and out but yells out that he is back. Unbeknownst to him, Booth is in the room and listening the whole time.

Once Booth reveals himself to Lincoln, the two brothers begin to lie to each other even though they both know the other is lying. Booth lies to Lincoln that he and Grace are now engaged. Lincoln lies to Booth that he now has a job as a security guard. Booth calls Lincoln's bluff and tells him that he must leave the apartment to make room for Grace. Lincoln quickly obliges. As Lincoln packs up his things, Booth brings up their father to stall Lincoln from moving out. Lincoln responds by referring to their father as a drunk. Booth then brings up the fact that their mom had a man on the side during their upbringing. This makes Lincoln launch into the truth about their father that Booth never knew. He declares that their father had more than one woman on the side and Lincoln would go with him to visit them when he was young. He would meet the women and sometimes his father would let him watch the two of them have sex. Lincoln also admits that he was sleeping with one of the women that his father slept with at the time.

With no other way to keep Lincoln around, Booth begs him to take a picture in his full Abraham Lincoln outfit. Lincoln gives in to Booth's request and puts his uniform on. Booth takes the picture. Then Lincoln asks for a picture of the two of them together. Booth says that he must save the film for his wedding day with Grace. Lincoln quickly shoots a jab at Booth about getting him a job at the arcade and the two brothers descend into another argument. Booth brings up the night he slept with Lincoln's ex-wife. He reveals that Cookie changed her mind and did not want to sleep with Booth, but he forced her to his bed and raped her. Lincoln does not react. He remains calm while the two continue to lob other insults at each other. The scene ends with Booth challenging Lincoln to a game of 3-card monte. Lincoln begins to throw the cards, but 
Booth says he is not playing for real and dares him to put the money he won from hustling up as a bet. After relentless taunting, Lincoln agrees.

Booth stops the game again and decides to put his inheritance up with the bet as well. After an intense game of 3-card monte, Lincoln beats Booth and wins both his money back and Booth's inheritance. Lincoln gloats and verbally destroys Booth in a long tirade, all while trying to undo a knot in the stocking containing the inheritance. He taunts Booth calling him a chump. He continues to berate him. This leads a clearly emotional Booth to exclaim that he killed Grace. He killed Grace because she rejected him. Lincoln tries to give the money back, but Booth will not accept it. He yells at Lincoln to cut the knot. Lincoln hesitantly goes back to trying to open the inheritance and Booth aims the gun at Lincoln's head. Lincoln only utters out one word, "Don't", before Booth shoots him in the head. After the shot, Booth paces back and forth in a deranged fashion. He proclaims that Lincoln "cannot take his shit". He then reaches to pick up Lincoln's money and finally comes to the realization of what he has just done. He crumples down onto the ground over his brother and proceeds to let out a wail. He cries over his brother's dead body as the lights fade to black. 


\title{
$\underline{\text { Text Analysis }}$
}

An actor must examine a character before performances take place. One must uncover why a character behaves the way they do and find their emotional depths. To do this with Lincoln, text analysis must be done. To ask the right questions, I used the nine questions from the "Respect for Acting” by Uta Hagen and Haskel Frankel. The nine questions are:

\author{
Who am I? (Character) \\ What time is it? (Century, year, season, day, minute) \\ Where am I? (Country, neighborhood, room, etc.) \\ What surrounds me? (Animate and inanimate) \\ What are the given circumstances? (Past, present, future and events) \\ What is my relationship? (To events, characters and things) \\ What do I want? (Character, main and immediate objectives) \\ What's in my way? \\ What do I do to get what I want? (Action: physical/verbal)
}

These questions uncover a deep sense of who a character is. It also examines the world they live in and their objective.

The first question is the most important to ask. "Who am I?". Who is Lincoln in the story of this play? How does he see himself and where is he at this point of his life? To start, Lincoln's job is in an arcade where he pretends to be Abraham Lincoln. He is an impersonator. This is seen in his first appearance described in the script. "Lincoln comes in quietly. He is a black man in his later 30's. He is dressed in an antique frock coat and wears a top hat and fake beard, that is, he is dressed to look like Abraham Lincoln.” (Parks 12). While Lincoln impersonates Abraham 
Lincoln, he knows it is not who he is. Lincoln considers it just a job. He is also an older brother. Lincoln and Booth at one time were children abandoned by both of their parents. In turn, Lincoln had to survive and help his brother survive. He became a good street hustler.

The first conversation Andra and I had about our characters dealt with our characters' ages. In the script, it states the age difference between the two brothers. "16 and 11 ain't grown." (Parks 71). We discover that there is a 5-year difference between the two.

The next two questions to answer is "What time is it?" and "Where am I?". These two questions go together. Andra, Jade and I discussed this topic. The script was not much help in this area. The script describes the setting as the following:

PLACE: Here

TIME: Now

(Parks 7)

To be specific, we had to decide where the play took place and in what time. Ultimately, we decided to place the play in the 90's in a New York tenement apartment.

The next question to ask was "What surrounds me?" Lincoln and Booth live in a cramped apartment together. The script describes it as follows: "Thursday evening. A seedily furnished rooming house room. A bed, a reclining chair, a small wooden chair, some other stuff but not much else.” (Parks 11). The reclining chair would become where Lincoln spends most of his time. The room also contains a 3-card monte set-up. "Booth practices his 3-card monte scam on the classic set-up: 3 playing cards and the cardboard playing board atop 2 mismatched milk crates." (Parks 11). The fact that there's 3-card monte set up in the apartment becomes very important in the text analysis. 
The next question is "What are the given circumstances?". There are many past and present given circumstances that affect Lincoln in this play. An important circumstance is Lincoln's history with 3-card monte. Lincoln is known on the street as one of the best 3-card monte players. He could hustle gullible people into playing and easily win their money. He states in this monologue to himself in Act 1, Scene 4 how great he is:

Hustling. Shit, I was good. I was great. Hell I was the be all end all. I was throwing cards like throwing cards was made for me. Made for me And me alone. I was the best anyone ever seen. Coast to Coast. Everybody Said so. And I never lost. Not once. Not one time. Not never. That's how much Them cards was mines. I was the be all end all. I was that good. (Parks 59)

After a while, Lincoln decides that he needs to leave his lifestyle of throwing cards, but not before his friend, Lonny, dies. After this incident, Lincoln decides to give up the cards for good, leading him on a downward spiral as he says in Act 1, Scene 3:

I swore them cards, took nowhere jobs, Drank. Cookie threw out, what the fuck Was I supposed to do? I seen that "Help Wanted" and I went up in there and I Looked good in the get up and agreed to do the whiteface and they really dug It that me and Honest Abe got the same name. (Parks 57)

This spiral leads him to take the job of an Abraham Lincoln impersonator and live with Booth in his apartment. Another important circumstance is Lincoln and his brother's history with their parents. Booth and Lincoln's parents left them when they were a very young as the brothers discuss in Act 2, Scene 5: 
Booth: They'd stopped talking to eachother. They'd stopped screwing eachother. But they had an agreement. Somewhere in there when it looked like all they had Was hate they sat down and did thuh "split" budget.

(Rest)

When Moms splits she gives me 5 hundred-dollar bills rolled up and tied tight in One of her nylon stockings. She tells me to put it in a safe place, to spend it only In case of an emergency, and to tell nobody I got it, not even you. 2 years later Pops splits and before he goes-

Lincoln: He slips me 10 fifties in a clean hankerchief: "Hide this somewheres Good, don't go blowing it, don't tell no one you got it, especially that Booth." (Parks 73)

When their parents left, they gave each child five hundred dollars as an inheritance. Due to this abandonment, Lincoln and his brother grew up on the streets. He learned how to play 3-card monte to help them survive.

Another given circumstance about Lincoln is his problem with alcohol. A trait most likely passed down to him from his father. This is evident when Lincoln speaks to Booth about their father in Act 2, Scene 6. "He was a drunk. Everything he did was always half regular, and half fucked up." (Parks 92). Lincoln refers to his father in this way but ironically, he is similar to his father. He and Booth use alcohol so much that they jokingly refer to it as "med-sin" and put aside money from Lincoln's paycheck to afford it. These given circumstances affect how Lincoln maneuvers through his world.

The last question I answered before rehearsals was "What is my relationship?". The main relationship Lincoln has in the play is his relationship with his brother, Booth. They are brothers 
in a constant state of competition. While there are good times between the two, they always try to one-up the other. This causes most, if not all, of the problems in their relationship. While there is love between them, the desire to be on top becomes more important.

Another significant relationship for Lincoln is with his ex-wife, Cookie. Even though Lincoln loved her, she threw him out when Lincoln was no longer making money from hustling. The complicated relationship between Lincoln and Booth worsens when they talk about her. In Act 1 Scene 3, Booth brings it up in an argument between the two. "You a limp dick jealous whiteface motherfucker whose wife dumped him cause he couldn't get it up and she told me so. Came crawling to me cause she needed a man." (Parks 50). Lincoln's reaction to this statement is not shock. A long silence occurs ending with the two angrily saying goodnight to each other. This leads me to believe that this is not new information to Lincoln. He already knows what Booth has done and has chosen not to confront him, but rather to move on. He chooses to not let Booth anger him, but Booth's constant poking at his manhood does culminate in Lincoln's choice to take Booth's inheritance and insults him ruthlessly at the end of the play.

The last important relationship for Lincoln is his relationship with his father. While he did not have much contact with his mother, his father made a large impression on him. It seems to me that Lincoln ends up as a carbon copy of his father. Lincoln drinks and sleeps with many different women just like his father as evident in the play. He drinks himself to sleep at the end of scene 2. At the end of scene 6, Lincoln recollects to himself how he had 3 women on him at the same time "Purrring all up on me and letting me touch them and promise them shit. 3 of them sweethearts in thuh restroom on my dick all at once and I was there my shit was there." (Parks 87). It comes as no surprise that Lincoln receives his inheritance from his father and not his 
mother. In Act 2, Scene 6, Lincoln tells Booth how his father would take him to go see women with whom his father had affairs:

Lincoln: Yeah? Pops had side shit going on too. More than one.

He would take me with Him when he went to visit them. Yeah, (Rest)

Sometimes he'd let me meet the ladies. They was all very nice. Very polite. Most Of em real pretty. Sometimes he'd let me watch. Most of thuh time I was outside On thuh porch or in thuh lobby or in thuh car waiting for him but sometimes he'd Let me watch. (Parks 93)

This affects the type of relationships Lincoln has with women. All the relationships Lincoln has with people in his life shape who he is, and how he carries himself. With the analysis questions answered, rehearsals soon began for Topdog/Underdog. 


\section{Rehearsal:}

\section{Tablework \& Inquiries}

The first day of rehearsal became a difficult one. The director, Jade King Carroll, flew into Pittsburgh from New York. She is an experienced director from New York who has many professional credits to her name. A lot of her theatre credits include directing the plays of August Wilson, a prominent African-American playwright. While I was ready to work with Cleo, Jade's background of directing plays about African-Americans seemed a perfect fit for the Topdog/Underdog. Andra and I were tasked with picking her up from the airport. On the ride back to the airport, the three of us began getting to know each other. After a collective three hours of travel going to and from the airport in a van with no air conditioning, we arrived at WVU with Jade ready to start rehearsals. After driving for that long, jumping into rehearsals was not something I wanted to do. The first day consisted of introductions of the cast and crew and a read-through of the play, followed with a conversation about the play. Even though I was tired, I became invigorated as we talked about it. In the first rehearsal, Jade talked about her love of the play and her desire to direct it. A rare feeling occurred about the process. Knowing everyone involved loved the play as much as I did and wanted to bring it to fruition gave me renewed enthusiasm to begin rehearsing.

The first rehearsal included asking some important questions about the world of the play. Since the play's setting does not give much detail about the time or place of the play, the three of us came to an agreement. Jade suggested that due to the size and layout of the apartment, there is a strong possibility that it takes place in New York City. Andra and I agreed. The idea that the play takes place in New York made sense to me. The first time I read the play, I assumed it was 
set in New York. Jade also suggested the play took place in the late 1990s. This made sense to me. The play was first produced in July 2001, so the 1990s is a great choice for the play.

We also discussed the characters' ages. While we knew of the five-year difference between the two brothers, it wasn't specific as to where in their 30's the brothers were. We came to the agreement that Lincoln was 34 or 35 with Booth being 29 or 30 . We also had a conversation about their connection to their parents. I found it interesting that in the play, Booth receives his inheritance from their mother while Lincoln receives his inheritance from their father. We discussed the possibility that Lincoln was closer to his father and Booth was closer to his mother. This information for me was confirmed through answering Uta's questions. Lincoln literally becomes his father and has the same vices his father does. After the first rehearsal, we were given some homework. My homework was to study 3-card monte videos and learn how to play the game well.

A big part of the play is 3-card monte. I had never seen 3-card monte played before and Lincoln is known as one of the best players around. It became very important for me to not only learn how to play, but how to play well. I began researching instructional videos of how to play 3-card monte. One specific video I watched was helpful. The video, titled "3-card Tutorial $\sim$ An In-Depth Tutorial" taught me the basics of playing 3-card monte. When I first started, I could not play. I have never been good at card tricks, so I knew this would be a challenge. I practiced as much as I could. I would carry 3 cards around with me during the day and play anytime I had free time. I also played half an hour before bed.

We continued to do tablework for the rest of the week. We read each scene, discussed it, and read it again. During this period, I had an emotional breakthrough about the character of 
Lincoln. Andra and I read the play together before rehearsals started, so reading the play again did not seem like it would change anything. At end of the week, we reread Scene 6 and things shifted. In scene 6, Lincoln comes back to the apartment with a handful of money and has returned to throwing the cards.

Reading such an emotional scene and knowing where it would go on our feet, I was hesitant to go there in the first week. A part of me worried about diving into the full emotion of the play too soon. I did not want to tie myself into a certain performance yet. After we read the scene the first time, Jade gave us notes on how we did. She said the scene lacked the tension and danger it requires. To earn the ending, we had to allow the build in the scene to affect us. This led to an idea. We could use a Meisner technique to help deepen the emotional effect. The Meisner technique, which can be found in his book Sanford Meisner on Acting is an acting method. We studied it in depth during our previous years at WVU. Meisner bases his method around observing and reading another person's behavior; to allow yourself to be affected by the words and behavior of the other person. During a conversation with Andra outside of rehearsal, we concluded that the entire play mirrors a Meisner exercise. The brothers interact based entirely off each other's behavior and react based off the perceived intent of that behavior.

Before reading scene 6 for the second time, Andra and I faced our chairs towards each other. We read the scene while looking at each other. We listened to the words being spoken. We read each other's behavior. The outcome of this became evident. To truly listen to the words being directed towards me made it the most intense read-through I have ever experienced. To take the words personally made me want to hurt him with my words even more. For the first 
time, I felt the ride of the scene. By the end of the read-through after Booth yells out in pain, we both found ourselves in a very emotional state. As an actor, it can be truly terrifying to not be in control of your emotions, especially at a read through. Andra and I separated to different places in the theatre. I needed time to be by myself and, in all honesty, be away from him. I experienced a flurry of emotions: pain, anger, sadness. All we did was read the scene and let ourselves be affected by it. Once we came back from a break, the tension still existed. I tried to be professional, but after an outpouring of emotion like that, it would take a while for me to calm down. The intensity of the Meisner session revealed to all of us that we had a show. 


\section{Preconceived Notions}

Before going into the rehearsal period, I had preconceived notions about the character of Lincoln and thought I knew how I wanted to portray him. When I read the play during the summer, I pictured Lincoln as an energetic character, both in voice and in movement. In terms of movement, I imagined a character who was not only smart, but quick. I related it to Michael Chekov's "Qualities of Movement", which we studied earlier in our training. In the book To the Actor by Michael Chekov, he discusses how different characters move through space. The main movements through space are molding, floating, and flying. Molding may be imagined as shaping the space around you. You cause the space around you to change as you move. As a result, a person who molds tends to move at a slower pace, affecting the space and people around them. The image Chekov gives for floating is to imagine yourself floating in water as you move through space. This gives the character a sort of ethereal feeling. The character differs from molding as not being as slow and can be seen more aloof while moving through space, as if nothing can really affect them. The image of flying that Chekov describes can be compared to flying in the sky, almost like a bird. A character who flies moves quickly through space. I imagined Lincoln's quality of movement to be flying.

I imagined that Lincoln's voice would never stay in his lower register. Using terminology that can be found in Freeing the Natural Voice by Kristin Linklater, as an actor, you should "imagine your body like a house. Put a sub-basement (foundation) below your rib cage, the basement in the chest, the lobby floor in the mouth, first floor from the mouth to the eyes, second floor from the eyebrows to the hairline, and the attic in the top of your skull." (275). Using this image, I envisioned Lincoln's natural center of resonance to live in his chest. When he got excited, his voice would move from his chest up to his mouth and maybe even his eyebrows. 
In all honesty, I wanted to play Lincoln in a way that I never previously experienced a character. The prior roles I had been cast in called for the character who mostly stood still whose voice sits in the sub-basement, or foundation, of the body. Most of the characters I previously played relied on stillness. Frankly, I wasn't interested in playing such a character again. I read the character of Lincoln and told myself this was my chance to perform differently from how I've performed characters in the past. I wanted to utilize all the training I received at WVU. I wanted to play with pitch and movement. The thought of playing a character completely different from myself excited me.

After we finished our read-throughs, we began moving on our feet. I played around with these ideas. Immediately, I met resistance. The director had a completely different idea of Lincoln. Anytime I tried to play with pitch, she would stop and tell me to go into my higher register. Anytime I would play with movement, the director asked me if that felt right to move around and directed me to stay put. Eventually, throughout a majority of the play, I ended up sitting in Lincoln's recliner. This began a period of extreme frustration. I wanted to play with my voice and with my movement. Instead, again my voice sat in my sub-basement. Instead of playing with movement, I stayed seated. My frustration hit its height when the director specifically told me she believed Lincoln to be more grounded in his voice and movement. Since, in the past, I had performed many other grounded characters whose strength comes from stillness, I wanted to explore other options with characterization, pitch, and voice. I had not anticipated feeling restricted in the beginning of this process. Indeed, I was in the midst of the actor's dilemma, our vision versus the vision of the director. 


\section{Musicality of the Language}

As the rehearsal process continued, Jade, Andra and I discussed the two brothers: how alike they were and how different they were. We concluded that the two brothers needed a similar family-based rhythm and sound. We both had to work together to achieve this sound. I was born and raised in the Washington DC area, in contrast, Andra grew up in the Atlanta area. We entered the process having two very different sounds. We needed to work at bridging the gap. We worked together and found certain words that we both said in the play and worked at saying them the same. There were several important words in the play that we had to be on the same page in terms of pronunciation. The biggest word being "cards". Cards is said frequently by both characters, so we needed to an agreement about how the word would be spoken. We agreed it should be said more like [kaidz], with a very light or even a removal of the /r/ sound in the word. Other words we agreed on were "ten" and "twenty". Ten and twenty are said often in play while Booth and Lincoln are playing 3-card monte. We came to the agreement that ten would be pronounced as [tIn] changing the / $/$ / to an /I/. Twenty we would pronounce as [tweni], dropping the second $/ \mathrm{t} /$ sound in the word.

Jade gave me many notes on needing to get more of a sense of the musicality of the language. Conversations took place about people who'd "forget their grandparents". Many people change their sound to fit the current social environment and then lose their connection to the past. During this period of rehearsal, self-doubt began to creep into my head. Would I be able to truthfully portray this African-American? It may sound ludicrous coming from a black male, but I doubted that I was black enough to perform in this play. Going into the rehearsal process and receiving the notes that I did made me question all of this. "Am I black enough to do this?" “Am I black enough at all?" “Am I good enough to play this role?” These questions raced 
through my head every time I got a note on language or physicality. My insecurities and anxiety were at an all-time high. I began to have feelings of inadequacy and worthlessness. However, once I began using Meisner to inhabit the character, the lines of the character and, in turn, the actor started to blur and be indistinguishable. 


\section{Point of View}

An exercise I used draws from chapter ten of Meisner's book, Sanford Meisner on Acting. The actor daydreams about the character and writes a journal entry from the character's point of view. This journal entry can be used as an entrance into the world of the play and the character's emotional state. After a frustrating run in rehearsal, I decided to write a journal entry for Lincoln. I chose to only write a journal entry for the top of the show since, for the rest of the show after my first entrance, it becomes a simple Meisner exercise where we read each other's behavior. Also, I was still finding difficulty in discovering who Lincoln is. I began to write through abstraction. I journaled from the perspective that Lincoln held at the beginning of the show. Lincoln had just given up the cards, the one thing that makes him special or even significant. His wife left him before that. He has been living with his brother for six months. He works at a job that he hates and comes home to a brother who insults him and takes most of his paycheck. Lincoln, at the top of the show, is a shell of a man.

I deciphered these given circumstances for the character and began to let that influence what I wrote. After writing three pages, I reread them. The lines rang very familiar to what I was experiencing at the time. Lines like "I feel defeated" or "feeling worthless" hit home for me as a person at the time. The rehearsal process up to this point had been draining. Receiving notes on my physicality, my voice and not getting the musicality of the language began to take its toll. I questioned if I was good enough on multiple occasions. In addition, to play a character that lives in that state daily becomes a strange experience. Aspects of Lincoln seeped into my personal life. In turn, I transferred aspects of my personal life to my portrayal of Lincoln. One line stood out to me as a summary of the psychological state of Lincoln. "I want to feel worth something for once." This became the line I prepped with before starting a run during rehearsals. In all honesty, 
I don't know for sure if I truly journaled from Lincoln's stand point or my own. I do know that what I wrote that day felt completely aligned with Lincoln's emotional state at the top of the show. I would use this entry anytime I did a run. I realized, after this Meisner exercise, that I had uncovered a big part of the identity of Lincoln. Pinpointing the internal and mental life of Lincoln helped me to discover his voice and his physicality.

As rehearsals progressed, I began to discover the emotional life of Lincoln, but still struggled to find a way to integrate the musicality of the language. Jade began playing 1990s rappers before rehearsals to get us into the world of the play along with the musicality of the language. A conversation began between the three of us about who Lincoln and Booth would favor between the iconic rappers, Tupac Shakur and Biggie Smalls. We discussed how Tupac's songs focused a lot more on lyrics. We also looked at what words he used and how he used them. Biggie focused more on riding the beat and going with the flow of the music. In comparing them, we decided that Lincoln would be a fan of Tupac. Booth would be more a fan of Biggie. After listening to Tupac throughout the rehearsal process, I found that Lincoln's use of words were similar to the way that Tupac used his. Lincoln is precise with his word and used his verbal arguments to inflict pain upon Booth. He knows that he can cut Booth by saying the right things. It was at this moment I really discovered Lincoln's edge, how he colors his language to attack. I started to find more points in the play for Lincoln to use his sharpness to cut Booth down in size. It immediately felt right. Jade even complimented me and told me to go even further with the edge I found with the language.

Another breakthrough came when Jade suggested we take the air out between the words. She wanted us to feel a quicker rhythm of the language than we were used to. To do this, we had a line-through where we would speak the lines very quickly. During this part of the rehearsal 
process, I finally sensed the rhythm of the language that she was listening for. While I did notice I rushed the lines, it became more natural to perform the lines in this way. No longer was every word precious, but the ones that were became the focus of the line. I related it back to listening to Tupac and Biggie. The use of language reminded me of how it is used when singing a song. Once I made the connection in my head, the quicker tempo became more natural; hence, the musicality of Lincoln became clearer for me. 


\section{$\underline{\text { Understanding Lincoln }}$}

The adjustment even began to affect my physicality and vocal production. It appeared to be more natural for Lincoln's voice to sit lower than I had originally imagined. He did not have to be loud or boisterous to assert his authority. He simply had to cut through and/or pierce someone with his words. For his physicality, I did not have to move around putting on a grand show of gestures. I could stand or sit in any part of the stage and feel incredible power from there. I likened this discovery to feeling akin to a lion. Anytime Lincoln sat in his recliner or stood still, he embodies strength. Aware of his power, he did not need to put on a show, for he knew he possessed this strength. He did not need to prove anything to anyone. Lincoln stayed in a state of readiness, prepared to pounce, but he did so only when it was required of him. During the last couple of rehearsals, it became clear what Jade's vision was for the two characters and the contrast between them. If Lincoln was a lion, then Booth was a yapping dog, jumping around trying to show how big and dangerous he was. Many of the differences between the two brothers became clear during these line-throughs.

One major difference became apparent between the two characters. Lincoln is extremely smart and does not feel the need to prove it. Booth is flashy and extreme but not as capable or confident as Lincoln. While Booth begs for Lincoln to teach him how to throw the cards and threatens to kick him out of the apartment, Lincoln is unfazed. Lincoln does not take Booth seriously as a card player, or even as a man. Another difference between the two is their choice of weapon. Booth prefers a gun while Lincoln prefers a knife. Booth carries his gun throughout the entire play, pulling it out at several different moments. He waves it around without care, trying to prove his masculininty. Lincoln uses a knife which requires more skill to use than a gun. It requires precision, strength and accuracy. A gun does not really require those skills in 
close range. With these differences coming to light throughout the rehearsal process, the older brother/younger brother relationship became clearer. Lincoln's attitude of discounting the ability of Booth comes from him being the younger brother. Lincoln teases Booth and knows how to push his buttons. It reflected my relationship with my older brother in that respect. I discovered these elements by playing with the rhythm of the lines. However, as every actor knows, the hardest part about playing with variety of the rhythm or acting choices, one must know the lines very well.

I underestimated how large an undertaking a two-person play would be for each of us. The biggest challenge of this play was memorizing the lines with complete accuracy. From the moment we got off-book a week and a half into rehearsals, lines, for both of us, were extremely spotty. So much so, that one day we would have the lines down for one scene, then forget them the next day. The repetition of words and lines became the main issue with memorization. Certain words are repeated in a way where it feels like no one would speak in real life. I believe certain lines were more musical in nature rather than with typical spoken word storytelling. It is true testament to the writing of Suzan-Lori Parks that she can write such realistic stories and yet have the language sound immensely poetic. However, from an actor's standpoint, it is difficult to learn. It also became extremely obvious when certain lines were incorrectly spoken, or when one of us switched around the words. The musicality of the language would be on a train then suddenly stop or completely change course. It became so difficult that we were doing linethroughs even during tech. 


\section{$\underline{\text { Last Missing Pieces }}$}

Both characters have their troublesome lines. Lincoln has a whole scene where he talks while Booth sleeps. To learn certain lines proved difficult to memorize. An important speech to memorize was when Lincoln speaks at length while also playing 3-card monte. Lincoln says the same lines anytime he plays 3-card monte. This speech can be found in Act 1, Scene 4 where Lincoln cannot resist the pull of the cards:

((Lean in close and watch me now: who see thuh black card who see thuh black Card I see thuh black card black cards thuh winner pick thuh black card that's Thuh winner pick the red card that's the loser pick thuh other red card that's Thuh other loser pick thuh black card you pick thuh winner. Watch me as I throw Thuh cards. Here we go. Who see thuh black card who see thuh black card? You Pick thuh red card you pick a loser you pick that red card you pick a loser you Pick thuh black card thuh deuce of spades you pick a winner who sees thuh deuce Of spades thuh one who sees it never fades watch me now as I throw thuh cards. Red losers black winner follow thuh deuce of spades chase thuh black deuce. Dark deuce will get you thuh win.)) (Parks 61)

Lincoln says this speech four different times in the play and every time it is a little bit different. The changes from "pick thuh other red card" and "you pick that red card" became hard to distinguish. I had to memorize the differences in these lines exactly. I usually never have difficulty with memorization in other shows, but this play tested me in that area. Our director, Jade, was also a stickler for the accuracy of lines. She would stop a run to correct us in the moment we changed or skipped a word. As I stated earlier, this led to many line throughs before 
rehearsals. Some rehearsals became just line-throughs. Another difficult speech can be found in Act 2 Scene 5, where Lincoln is discussing the difficulty their parents had in raising them:

I think there was something out there that they liked more than they liked us And for years they were struggling against moving towards that more liked Something. Each of them had a special something they was struggling against Moms had hers. Pops had his. And they was struggling. We moved out of that Nasty apartment into a house. A whole house. It wern't perfect but it was a house And they'd bought it and brought us there and everything we owned, figuring We could be a family in that house and them things, them two separate things Each of them was struggling against would just let them be. Them things would See thuh house and be impressed and just leave them be. Would see the job Pops Had and how he shined his shoes every night before he went to bed, shining them Them shoes whether they needed it or not, and thuh thing he was struggling Against would see all that and just let him be, and thuh thing Moms was Struggling against, it would see the food on the table every night and listen to her Voice as she read to us sometimes, the clean clothes, the buttons sewed on all Right and it would just let her be. Just let us all be, just regular people living in a house. That wern't too much to ask. (Parks 71)

The repetition of "struggling" and "thuh thing" makes this speech very difficult to learn. This is a clear example of the lines in the play sounding more like poetry than a linear story. Even though it is grueling, it became one of my favorite speeches after I finally got it down. The lines were not the only hardship we found as we moved from rehearsal into tech week.

Another difficulty experienced was not having props or costume pieces. Topdog/Underdog is a very prop-heavy show. The props are important in telling the story. From 
an actor's standpoint, it is extremely helpful to have the props early on to get accustomed to them. Costumes in this play are also important to work with. There are costume changes that happen on stage. For instance, in Act 1 Scene 2, the two brothers change out of their clothes and into suits, all while continuing to speak to each other. The two brothers must be finished changing by the time Booth says his line "Sharp, huh?" (Parks 34). This only gave us a limited amount of time to change into the suits. Later in the same scene, Lincoln takes off his suit and puts on his Lincoln outfit. It would have been beneficial to work on changing in and out of the costume pieces early on, but we received the suits during tech week. This made tech week tense in terms of not only having to be aware of our lines and blocking, but also adding in the new costumes and props that we did not have during rehearsal. Another prop we had never worked with was blood.

At the end of the play, Booth shoots Lincoln in the back of the head. Jade was adamant about having blood pooling on the stage. In tech week, there were many experiments that occurred to find out where the best place was to put the blood bag. Lincoln was shot, so I needed to turn and fall on my back. We tried putting the blood bag in Lincoln's hat. This would prove to be ineffective because the hat would shift as I fell, and the blood bag would not open. Eventually a solution had to be found. We tried placing the blood bag on my back. Lincoln is wearing his Abraham Lincoln outfit during this scene. This includes his hat and his frock coat. The costume designers put a pocket in the top of the frock coat behind my neck. During the scene, it became my job to undo the tie that kept the blood in. When I fell I intentionally landed on the bag and, for the first time, the blood bag opened, and blood pooled out around my neck. After a long rehearsal process fraught with pitfalls, we finally had everything we needed to open the show. 
By the end of the rehearsal period, I became aware that I had discovered the character of Lincoln. He wasn't who I thought when we started rehearsals in August. The character I found, using a lower vocal register and a grounded physicality and nature, felt aligned with the written text. Finally, I found the musicality of the language and enjoyed playing with it. I also found Lincoln's edge and the moments he used to stab his brother using his words and the actions accomplished through those words. I unexpectedly found physical gestures and movements that opened a greater depth of the character's life. Gestures I found included wiping my nose with my thumb and pointer finger, also rocking back and forth began to occur naturally. It took a long time, but I finally found Lincoln and I also felt ready for an audience. However, I also worried about their reaction to this play.

As we moved closer to opening night, I worried about how the play would be received by people in this region of the country. Performing a play about two African-American brothers in West Virginia amidst the current political and social climate made me feel anxious. How would the audience interpret what they were seeing? Would they hate it? Would people even stay to watch it, or would they walk out? I began to worry whether it was dangerous to perform it for this particular audience. Jade said at the beginning of the rehearsal process that doing this play in this area was very important to her. She said people needed to see this play, especially because of the state of our country at the time. I believed what she said and agreed, but that didn't take away my concern. It took me back to the mindset right after Trump won the presidency where there was a palpable sense of fear for many of us. I did not like feeling afraid to perform a story that I had loved for so long. A story we all put so much time and effort to create. While I was concerned how the show would be received by the audience, I was not going let that stop me from putting my best work into our performance. 


\section{Performance:}

\section{Getting into Character}

Before the performance, I began a ritual of exercises to warm up and get into the mindset of Lincoln. I started by checking for all my props onstage. Since props are such a big component of the play, it became vital for me to check that everything was in its place. While on stage, I would do the Vocal ladder and House of resonance exercises which can be found in Linklater's book Freeing the Natural Voice (187). During these exercises, an actor goes through each resonator of the body to warm up the voice and allow for each to be accessible during a performance. I began Fitzmaurice's destructuring Tremorwork.

Destructuring, the first phase, promotes awareness of the body, spontaneous and free breathing, vocal expressivity, and presence, through Tremorwork $®$ and sometimes hands-on interventions. Tremorwork $®$ encourages students to allow uncontrolled shiverlike oscillations to flow through their entire bodies, making chronic tension blocks apparent and helping to release them. (Fitzmaurice)

Tremorwork allowed me to more deeply warm up vocally and physically. After tremoring, I started my pre-show ritual. After Andra left the room, I gathered my Abraham Lincoln attire, which included my frock coat, my top hat, my shirt and vest, and my beard. I slowly got dressed into the outfit while looking at myself in the mirror. I always had my Meisner journal nearby, so I could read it aloud as I got dressed. As stated before, the journal contained my abstract writing from Lincoln's perspective. To look in the mirror and see myself dressed in the Lincoln outfit was a surreal feeling. As I put the white make-up on my face, feelings of inadequacy began to surface. I was instantly put back into the character of Lincoln. To be a black man having to put on white face make-up to play a white man for a minimum-wage job felt demoralizing. As I put 
the make-up on, I repeated over and over the summary line from my freewriting session. "I want to feel worth something for once.” After all my physical and vocal exercises, this ritual placed me in the mindset of Lincoln at the top of the play. Once I finished I went downstairs, ready to start the show physically and emotionally alive. 


\section{Showtime}

The performances became a surreal experience, from opening to closing night. All the shows were different in some way, shape or form. The one constant throughout the entirety of the run was that I never felt alone onstage. I have been in much larger casts and felt alone on stage. I sometimes have had a sense that if something goes wrong, I do not particularly trust the other actors enough to help. In this case, with Topdog/Underdog being a two-person play, trust must absolutely be present between the actors. In every performance, I felt Andra and I were connected on stage. Even when mistakes with props or lines occurred, which happened almost every show, we stayed connected. If a prop malfunctioned or a line was dropped, we trusted each other enough to know that the show would go on. With that trust being the foundation of each show, every night of the play became a roller coaster of emotions. A roller coaster that I jumped on at the beginning of the play and rode until the very intense and emotional end. When something did go wrong, we made sure never to let it stop or hinder the show.

With a show that has many props, costumes and elements, the likelihood of something going wrong significantly increases. As I said, every night something went wrong. For instance, in the first scene, Lincoln and Booth are eating Chinese food and drinking canned sodas. During the Saturday matinee, the canned soda I drink fell on the ground. I tried to open it slowly to let air escape. The soda then proceeded to spray all over me, including on my costume, all for the entire audience to witness. I looked at Andra who looked just as shocked as I was. I then proceeded to say, "The shits still good". I found it funny but tried hard not to break character. We continued the scene like usual, but the moment still caught both of us off-guard. Little instances like this transpired throughout the entire run. One performance, there was a mishap with a pee-bag. In Act 1 Scene 4, Lincoln pees into a cup onstage which required me to wear a 
pee-bag. One night, the pee-bag slipped out of my pants onto the floor. Again, I was shocked, but kept the show moving. Even though many mishaps occurred, all the performances would reach the required height of emotional energy.

The emotional energy that I felt after a show became hard to shake. After a performance, Andra and I went upstairs to the dressing room and literally changed out of our costumes in silence. After most shows, I could not even force myself to utter a word to him. Looking at myself in the mirror, covered with fake blood disturbed me immensely. It filled me with anger and sadness. After the show, I would vigorously scrub the blood off myself because I couldn't bear to look at my reflection. As I got out of costume, I internalized the feelings from the show. The performance was over but lingering emotions from Lincoln's character still remained after the performance.

As an actor, it is expected that a character will stay with you for a little while after a show, especially with a show like Topdog/Underdog. The main issue for me became letting Lincoln be his own entity. Lincoln was a character with whom I spent two months living and commiserating. I related to him and the way he saw the world. Likewise, I fused many of my own insecurities into Lincoln. Letting go of the emotions from the show was not easy, especially given that, as an actor, you must find a way to tie your personal experiences and flaws into a performance. As this character, Stanislavski's 'magic if' becomes a living breathing life on stage. This situation can be likened to the psychological effects of method acting, where one uses previous personal experiences to fuel emotional moments on stage. The danger becomes when an actor uses unresolved emotions to stimulate acting moments or characters. I never had any intention to do this, but I realize that the unresolved emotions throughout the rehearsal process 
bled into my character. I never discovered a way to properly disengage from Lincoln after a show during the run. This is the reason why it became so difficult to let the character go.

Usually when I am performing in a show, I will leave without seeing anyone in the audience. Since this show only has two people and people usually wait afterwards to talk to the actors, I forced myself to put on a smile to say $h i$ to audience members. It would not be until the car ride home when I finally felt I had shaken the feelings I experienced during the show. For the most part, I would be able to let them go, but some lingering feelings took longer to shed. This feeling post-performance made me realize that there was never a show where I could totally release the emotional weight and energy of Lincoln's life. The feedback we received after the show reflected that the audiences felt the same. 


\section{$\underline{\text { Evaluation }}$}

The feedback we received from the show was outstanding. People were moved by the story and the acting. I was taken aback by the reaction. I expected the complete opposite reaction. To find out the audiences loved the show made me very proud of all the work we did. The students and faculty at WVU had nothing but complimentary things to say about the play. The show had an impact on audiences. Themes of family, competition, desperation, and ultimately love are things with which we all can connect. That was proven to me throughout this experience. Overall, there were several thoughts/ideas I took away from Topdog/Underdog that I will carry with me as an actor and a person.

The first thought that I will take away reminds me to come into a rehearsal or any experience with an open mind. I have worked with directors who know what they want. In those instances, I went in with the intention to find the character through playful exploration. This was a different experience. I had things that I wanted to play with and I was not allowed to. Directors are all different. Some directors come in knowing exactly what they want for the characters and some directors want to find out who the character is through the rehearsal process. In Jade's defense, she did not cast the show. She had no chance to meet the two actors with whom she would work. She had no choice but to study the play and know exactly who these characters are from the very first day of rehearsal. We had different perceptions of the physical and vocal life of Lincoln, but overall, many of our thoughts about Lincoln as a person aligned with each other. Halfway through the rehearsal process, Jade would tell Andra and I that she would have cast the show exactly how it happened, which was encouraging. Even though there were aspects of the character I wanted to play around with, I should not have let my preconceived notions about the 
character cloud who the character is. I wanted to play with pitch and voice, but it should not be at the character's expense.

The second thought I walked away with: be confident in myself as a person. The amount of time I spent with anxiety, self-doubt and feelings of inadequacy about this character and about myself became a burden. I feared that I was not good enough to play this character, afraid that I was not black enough to play this character. This play hit a lot of insecurities that I have but I should not have let it affect me to the extent that it did. As much as I love this character, no amount of feedback or notes should make me doubt who I am outside of the play, but this time I let it get to me. I let it seep into my daily life and eat away at me. Ultimately, these thoughts did help me to connect with Lincoln more and it led to the final performance and character, but I was left with the question "Was it worth it?" Looking back, I believe it was important for me to go on this journey if only for the lessons it taught me. The separation between character and self is vitally important. Walking away after a rehearsal or performance, knowing what happened in the space is different from life outside of the space. To know these differences was an essential and difficult learning process. I should not have let this process affect how I felt about myself. At the end of the day, a character is a character and I am myself. It is important to fulfill a character's life, it is our job as actors to commit to that fully. Our other job as actors, which is just as important, is to leave the character behind once we've left the stage and not to bring them with us. 


\section{$\underline{\text { Conclusion }}$}

Topdog/Underdog is an extraordinary play with two deep, troubled but inspiring characters. I will always remember my experience in playing Lincoln. He is by far my favorite character that I have portrayed. I might have the desire, years down the line, to revisit the character knowing what I know now. I might even have the desire to play Booth. Looking back on the entire process, I am thankful for everything that I was able to accomplish. As an actor, even when you have prepared as best as one thinks possible, you are never really prepared to go into the depths of a character. It is frightening to confront aspects about the character that are like you. I am proud to have been through this experience and arrive on the other side. The play, the character, Jade and Andra, have all taught me so much about myself and who I am as an actor. I am also proud to know that people were affected by the play. To have a desire since my first year of grad school to do this powerful play and have it come to fruition is an amazing feeling. Even more incredible is how so many people were moved by this play about two African-American brothers. At the end of the day, the play is about two people trying to live life through adversity and tribulation, and that is something with which everyone can connect. 


\section{Bibliography}

3 Card Monte An In-Depth Tutorial. YouTube, 31 Mar. 2016, youtu.be/QJv44-Ghj_Y.

Chekhov, Michael, Mala Powers, Simon Callow, Yul Brynner, and Andrei Malaev-Babel. To the Actor. 2002. Print.

Fina, Anna De. "Code-Switching and the Construction of Ethnic Identity in a Community of Practice." Language in Society, vol. 36, no. 3, 2007, pp. 371-392. JSTOR, www.jstor.org/stable/4169611.

Fitzmaurice Voicework - About, www.fitzmauricevoice.com/about.htm.

Hagen, Uta, and Haskel Frankel. Respect for Acting. New York: Macmillan, 1973. Print.

Hamden, Raymond. "Clinical and Forensic Psychology". Interview. Dubai Today. Arabian Radio Network. Dubai. 14 April 2010. Radio.

Konin, Elly A. “Acting Emotions: Shaping Emotions on Stage.” Amsterdam University Press, 2000. 89-102.

Linklater, Kristin. Freeing the Natural Voice: imagery and art in the practice of voice and language. Drama Publishers, 2006.

Meisner, Sanford, and Dennis Longwell. Sanford Meisner on acting. W. Ross MacDonald School Resource Services Library, 1987.

Parks, Suzan-Lori. Topdog/Underdog. Dramatists Play Service, 1999.

Three Card Monte Scam (Tutorial). YouTube, 28 Dec. 2011, youtu.be/nvkIGyxD-W8. 